\title{
Peranan Kinerja Dalam Meningkatkan Efektivitas Kerja Karyawan Pada PT. Bumi Alam Persada Ogan llir
}

\author{
Muhammad Najib \\ Pendidikan B. Inggris, FKIP Universitas PGRI Palembang,mn760503@gmail.com
}

\begin{abstract}
ABSTRAK
Metode yang digunakan dalam penelitian ini yaitu deskriptif kualitatif. Sedangkan Teknik pengumpulan datanya dengan melakukan observasi dan wawancara pada objek penelitian. Hasil yang diperoleh untuk dapat terwujudnya pelaksanaan kerja dengan baik dalam usaha meningkatkan efektivitas kerja, maka faktor manusia perlu diperhatikan karena manusia merupakan faktor yang paling penting dalam menentukan berhasil atau tidaknya melaksanakan tugas dan tanggung jawab yang dibebankan kepada mereka dengan sebaik-baiknya. Pada PT. Bumi Alam Persada Ogan llir Kegiatan efektivitas kerja belum dilaksanakan sepenuhnya dimana masih adanya tugas rangkap yang dilaksanakan di dalam PT. Bumi Alam Persada Ogan llir. Seorang pemimpin harus bisa menempatkan orang-orang yang sesuai dengan bidang dan kemampuan masing-masing agar tujuan dan sasaran dapat tercapai sesuai dengan rencana. Dari hasil analisa ini peneliti menyarankan agar lebih meningkatkan efektivitas kerja sehingga dapat melaksanakan pekerjaan secara efektif dan efisien sebaiknya jabatan rangkap harus dihindari. Untuk lebih meningkatkan efektivitas kerja, hendaknya seorang pimpinan harus lebih memperhatikan pengetahuan, keterampilan dan pengembangan kemampuan bagi karyawan, caranya dengan mengadakan pendidikan dan pembinaan sehingga karyawan tersebut akan lebih menyadari terhadap tugas dan tanggung jawab yang dibebankan kepadanya. Pimpinan sebaiknya dapat mendelegasikan wewenang kepada bawahannya sesuai dengan keahlian yang dimiliki agar efektivitas kerja dapat tercapai dan sesuai dengan tujuan yang diharapkan.
\end{abstract}

Kata kunci : Peranan kinerja, Efektivitas Kerja

\section{A. PENDAHULUAN}

Keberhasilan suatu organisasi

baik besar maupun kecil bukan semata-mata ditentukan oleh sumber daya alam yang tersedia, akan tetapi banyak ditentukan oleh kualitas sumber daya manusia yang berperan merencanakan, melaksanakan dan mengendalikan organisasi yang bersangkutan. Pada dasarnya, untuk melaksanakan rencana-rencana sesuai dengan hasil yang diharapkan kemungkinan adanya hambatan yang tidak terduga, Untuk mengatasi hambatan tersebut perlu dijalankan fungsi-fungsi manajemen.

Adapun fungsi-fungsi manajemen yaitu Planning, Organizing, Actuating, dan Controlling. Fungsi-fungsi manajemen tersebut tidak dapat dipisahkan antara satu dengan yang lainnya, karena diantara fungsi-fungsi itu terjadi suatu keterikatan yang nyata serta saling melengkapi antara satu fungsi dengan fungsi yang lainnya. Manajemen sumber daya manusia yang dilaksanakan dengan baik akan memberikan kontribusi yang cukup besar dalam usaha mencapai sasaran organisasi atau perusahaan. Manajemen sumber daya sebagai pendekatan stratejik dan koheren untuk mengelola aset paling berharga milik organisasi, orang-orang yang bekerja dalam organisasi, baik secara individu maupun kolektif dan memberikan sumbangan untuk mencapai sasaran organisasi. Manajemen sumber daya manusia sebagai bagian dari manajemen keorganisasian yang menfokuskan diri pada unsur sumber daya manusia.

Adapun lingkup manajemen sumber daya manusia adalah 
pengadaan, pengembangan dan pemanfaatan sumber daya manusia. Pengadaan sumber daya manusia adalah menyediakan tenaga kerja yang dibutuhkan organisasi secara kuantitatif dan kualitatif. Pengembangan sumber daya manusia adalah program yang khusus dirancang oleh organisasi dengan tujuan membentuk karyawan dalam meningkatkan kemampuan kinerja, pengetahuan dan memperbaiki sikap melalui berbagai macam efektivitas. Pemanfaatan sumber daya manusia adalah proses kegiatan pimpinan yang bermaksud mempekerjakan pegawai yang memberi prestasi kinerja karyawan yang cukup dan tidak mempekerjakan pegawai yang yang tidak bermanfaat.

Tujuan perusahaan dapat tercapai sesuai dengan yang direncanakan maka kegiatan kegiatan yang ada dalam perusahaan harus saling menunjang satu sama lainnya. Agar tujuan perusahaan dapat dicapai secara efisien dan efektif, artinya dari waktu ke waktu yang ditentukan kegiatan perlu diatur dengan baik. Untuk mencapai tujuan tersebut, maka perlu diperhatikan masalah manajemen yang turut serta mengembangkan faktor-faktor tenaga manusia supaya dapat menggerakan bawahannya untuk dapat bekerja lebih efektif, karena manajemen merupakan tulang punggung suatu kantor. Seorang pimpinan harus membuat perencanan yang harus mempertimbangkan sumber-sumber sarana yang telah tersedia, pimpinan juga harus dapat bekerja sama dengan bawahanya dalam mencapai tujuan perusahaan.

Membangun dan mengelola kinerja melalui sistem manajemen kinerja adalah membangun harapan yang nyata untuk mencapai optimalisasi, dimana manajemen kinerja mencakup proses pengajian terhadap kinerja berkisinambungan yang dilakukan secara bersamasama dengan kesepakatan dengan sasaran, persyaratan pengetahuan, termasuk rencana peningkatan dan pengembangannya.

Kinerja karyawan sangat diperlukan untuk mencapai prestasi setinggi-tingginya dan sebaikbaiknya. Untuk mewujudkan kondisi ini maka diperlukan cara yang tepat untuk mengupayakan agar semua unsur yang terlibat dalam perusahan tidak menyimpang dari kinerja yang telah disusun sebelumnya, disinilah penting diketahui faktor-faktor yang berperan dalam menunjang keberadaan efektivitas karyawan.

\section{B. LANDASAN TEORI}

1) Pengertian Kinerja

Kinerja adalah tingkat pencapaian hasil atas pelaksanaan tugas tertentu. Prestasi kerja adalah hasil yang dicapai oleh seorang karyawan dalam melaksanakan tugas yang diberikan kepadanya. Manajemen adalah suatu proses mengkombinasikan dan mendayagunakan semua sumbersumber secara produktif untuk mencapai tujuan perusahaan atau organisasi.

Menurut Payaman J. Simanjuntak (2005:17) Manajemen kinerja adalah keseluruhan kegiatan yang dilakukan untuk meningkatkan kinerja perusahaan. Manajemen kinerja merupakan proses berkelanjutan untuk siklus, terdiri dari perencanaan, pembinaan dan evaluasi.

Para ahli dalam ilmu manajemen memberikan batasan tentang pengertian dari kinerja. Pengertian kinerja karyawan secarah umum adalah erat kaitannya dengan usaha pencapaian tujuan dan sasaran yang telah ditentukan 
sebelumnya oleh perusahaan, sehingga seringkali tujuan dan sasaran yang ingin dicapai dijadikan tolak ukur dari pelaksanaan.

Organisasi yang telah mengembangkan sistem manajemen kinerja yang efektif memperoleh imbalan berupa produktivitas, kondisi kerja yang bermutu, dan ketaat hukum. Karena tujuan ganda evaluasi dan pengembangan konflik dalam sistem penilaian tidak bisa dihindari. Konflik-konflik ini, jika tidak diperhatikan akan melumpahkan efektivitas sistem manajemen kinerja manapun.

Meskipun banyak teori motivasi menjelaskan kinerja manusia dalam organisasi satu kerangka diagnostik telah disediakan untuk membantu para penilai mendapatkan akar penyebab suatu permasalah kinerja. Dengan menggunakan kerangka ini untuk memahami kesenjangan kinerja, akan diperoleh suatu dasar untuk memilih strategi yang berbedabeda guna meningkatkan kinerja. Dari sudut pandang pengembangan strategi yang melibatkan partisipasi dan kejelasan tugas mendorong perbaikan yang diarahkan oleh diri sendiri.

Manajemen kinerja ini berkaitan dengan usaha, kegiatan atau program yang diprakarsa dan dilaksanakan oleh pimpinan organisasi (perusahan) untuk merencanakan, mengarahkan dan mengendali kinerja karyawan. Program manajemen kinerja ini mencantumkan kata manegement, seluruh kegiatan yang dilakukan dalam sebuah " proses manajemen" harus terjadi dimulai dengan menetapkan tujuan dan sasaran yang ingin dicapai, kemudian tahap pembuatan rencana, pengorganisasian, pengarahan dan akhirnya evaluasi atas hasilnya. Secara teknis programini memang harus dimulai dengan menetapkan tujuan dan sasaran yaitu " kinerja" dalam bentuk apa yang seperti bagaimana"yang ingin dicapai, karena yang menjadi obyek adalah kinerja manusia, maka bentuk paling umum tentunya adalah kinerja dalam bentuk "produktivitas" sumber daya manusia.

\section{2) Tujuan Kinerja}

Tujuan pokok kinerja adalah untuk memotivasi karyawan untuk mencapai sasaran organisasi dalam memenuhi standar perilaku yang telah ditetapkan sebelumnya agar membuahkan tindakan yang diinginkan.

Menurut Sulaiman Sukmalana (2007:76) Tujuan kinerja adalah sebagai berikut :

a) Tujuan strategis

Yang pertama dan paling penting dalam sistem manajemen kinerja adalah perluhnya keterkaitan antara aktivitas karyawan dan tujuan organisasi. salah satu cara yang dapat dilakukan adalah mendefenisikan kriteria hasil, perilaku dan faktor pendukung lain.Untuk mencapai ini semua diperlukan sistem yang fleksibel, karena pada saat diperlukan perubahan tujuan dan strategi, maka perilaku dan karakteristik karyawan yang diperlukan juga beruba secara berkesinambungan.

b) Tujuan administratif

Perusahaan / organisasi mengunakan informasi pengelolaan kinerja untuk berbagai kebijakan administratif, seperti administrasi pengajian (kenaikan gaji), promosi, mempertahankan dan memperhatikan karyawan, 
pemberhentian karyawan sementara dan penghargaan kinerja individu. Pengelolaan kinerja yang efektif akan tercapai apabila hasil memiliki konsekuen pada umpan balik, sistem reward (peningkatan gaji) dan keputusan lain.

c) Tujuan Pengembangan

Tujuan ketiga dari penilaian kinerja adalah mengembangkan karyawan secara efektif pada pekerjaan mereka. Ketika karyawan tidak mampu menunjukan hasil kerja sesuai harapan yang seharusnya dilakukan maka organisasi perlu menyelenggarakan program pengembangan karyawan.

Menurut Payaman J. Simanjuntak (2005:33) Tujuan perusahan atau dunia bisnis lebih mudah dirumuskan secara kuantitatif dibandingkan perumusan tujuan lembaga Pemerintah. Dengan demikian strategi perusahaan lebih mudah dirumuskan dari strategi lembaga Pemerintah. Strategi disusun dengan :

$\checkmark$ Berdasarkan visi dan misi perusahaan.

$\checkmark$ Mempertimbangkan keunggulan dan kemampuan khusus yang tidak dimiliki oleh perusahaan lain serta keterbatasan dan kelemahan internal organisasi.

$\checkmark$ Memperkira peluang serta hambatan dan tantangan dari luar perusahan, termasuk potensi daya beli masyarakat dan kekuatan pesaing.

Untuk mencapai tujuan dan menjalankan strategi perusahan tersebut disusun struktur organisasi dengan perusahan yang jelas mengenai fungsi masing-masing unit organisasi, uraian jabatan, sasaran kinerja dan rencana peningkatan kinerja.

Berbagai aspek yang mendasar dalam masalah kinerja karyawan/sumber daya manusia dalam banyak hal menunjukan suatu varitas yang sangat komplek pada suatu organisasi/perusahaan. Kompleksitas kinerja yang dicapai karyawan/sumber daya manusia karena menyangkut terhadap karakteristik dan perilaku individu yang interaksi dengan lingkungan sehingga sering kali tidak dapat secara pasti untuk ditetapkan dan diprediksikan.

\section{3) Peningkatkan Kinerja}

Menurut Sulaiman Sukmalana (2007:78) Peningkatkan pada pada dasarnya dapat diuraikan melalui kebijakan seperti berikut :

a. Tetapkan Standar dan Tujuan Kinerja

Standar adalah tingkat minimum kinerja yang diterima, Tujuan adalah tingkat kinerja yang ditargetkan. Keduannya harus ditetapkan dan harus dikaitkan langsung dengan pekerjaan. Tujuan dan Standar harus dapat diukur dan dicapai, tujuan harus menantang tetapi tidak mustahil diraih kesempurnaan tidak perna mungkin. Tujuan dan Standar sebaiknya dibentuk dengan dasar pengamatan dan logis.

b. Manfaat Data Kinerja yang Tepat

Menghindari dan mengurangi konflit dan perbedaanperbedaan persepsi terhadap ranting kinerja adalah memanfaatkan data kinerja yang terfokus pada tujuan dan 
perilaku tertentu, hindarkan data kinerja yang terfokus pada sifat dan karakteristik pribadi karena dapat mendorong sikap defensif, karena manajer tidak boleh memberi alasan sebagai kewenangan dan citra dari pada bawahan dan jangan memperlakukan karyawan dengan mengkritik perilaku secara individu dalam tindakan pekerjaan.

c. Berdayakan karyawan

Hal yang sulit dalam proses manajemen kinerja melakukan evaluasi/penilaian adalah mengumpukan dan mengelola informasi mengenai semua karyawan.

d. Lakukan audit kinerja

Audit kinerja penting dilakukan untuk mengkaji seberapa baik kerjaan dilaksanakan, tanpa audit banyak manager yakin bahwa operasi mereka berjalan tidak lebih baik dari pada yang sesunggunya.

e. Berikan umpan balik mengenai kinerja

Pada tahap ini program dorongan positif adalah memberikan data dasar yang dibutukan karyawan untuk memantau pekerjannya sendiri, karena dalam banyak kasus standar kinerja kebanyakan pekerjaan dinyatakan secara jelas, bahkan ketika dinyatakan dengan jelas standar itu jarang sekali tersedia bagi karyawan.

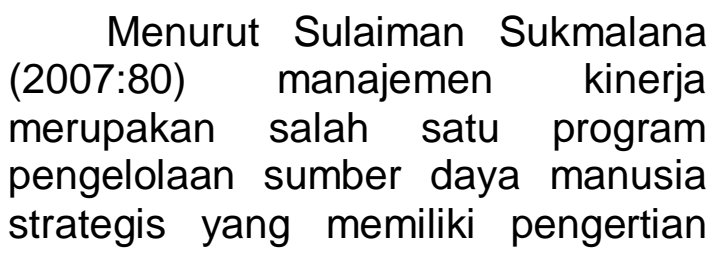

penting dari sudut pandang karyawan dan organisasi.

Dari sudut pandang organisasi, program ini merupakan kewajiban yang harus dilakukan, sebab organisasi memiliki kepentingan untuk memastikan kesesuaian antara hasil kerja staff/karyawan dengan tanggung jawab dan peran yang tercermin dalam deskrifsi pekerjaan yang mendorong pencapaian sasaran organisasi. Dengan adanya penilaian kinerja maka dapat diidentifikasikan perbedaan kontribusi yang diberikan karyawan kepada organisasi yang akan mempengaruhi kebijakan dalam pengembangan sumber daya manusia dan peran serta tanggung jawab para manajer / pimpinan dalam suatu perusahaan / organisasi.

Dari sudut pandang karyawan, program ini merupakan hak yang selayaknya diterima sebagai kontekwensi penerimaan tanggung jawab, sehingga dapat mengukur kemampuan dengan bekal potensi dan kopotensi yang mereka miliki. Pengelolan/manajemen kinerja efektif akan mampu membangun perilaku sesuai harapan organisasi, seperti sikap, kepuasan, komitmen dan kesadaran pengembangan diri. Hal tersebut perlu menjadi perhatian manajer dalam setiap kebijakan operasional, keberhasilan pencapaian tujuan organisasi dan seberapa besar efektivitas yang akan di capai akan tergantung dari kontribusi pada karyawan (sumber daya manusia) dan bagaimana manager mampu mengendalikan.
Menurut
Payaman
$J$.

Simanjuntak (2005:109) peningkatan kinerja adalah sebagai berikut :

1. Kemampuan tertentu sebagai dasar untuk mengembangkan diri lebih lanjut 
2. Keinginan untuk terus belajar dan meningkatkan kemampuan kerja

3. Sikap tertarik pada pekerjaan dan etos kerja yang tinggi

4. Keyakinan untuk berhasil

\section{4) Evaluasi Kinerja}

Menurut Payaman J. Simanjuntak (2005:103) Evaluasi kinerja adalah suatu metode dan proses penilaian pelaksanan tugas seorang atau kelompok orang atau unit-unit kerja dalam satu perusahaanatau organisasi sesuai dengan standar kinerja atau tujuan yang ditetapkan lebih dahulu.

Kinerja individu adalah tingkat pencapaian atau hasil kerja seseorang dari sasaran yang harus dicapai atau tugas yang harus dilaksanakan dalam kurun waktu tertentu. Kinerja perusahan atau organisasi adalah tingkat pencapian sasaran atau tujuan yang harus dicapai oleh perusahan tersebut dalam kurun waktu tertentu.

Evaluasi kinerja berarti memberi nilai atas pekerjaan yang dilakukan oleh sseorang dan untuk itu diberi imbalan, kompensensi atau penghargaan. Evaluasi kinerja merupakan cara yang paling adil dalam memberikan imbalan atau penghargaan kepada pekerja.

Menurut Payaman J. Simanjuntak (2005 : 106) Tujuan Evaluasi kinerja adalah untuk menjamin pencapaian sasaran dan tujuan perusahaan. Evaluasi kinerja perusahaan dilakukan untuk mengetahui posisi perusahaan, terutama bila terjadi kelambatan atau penyimpangan. Bila terjadi kelambatan harus segera dicari penyebabnya diupayakan mengatasinya dan dilakukan pencepatan.

Kinerja perusahaan merupakan akumulasi kinerja unit-unit organisasi dan kinerja semua individu mulai dari pekerjaan operasional hingga manajemen. Oleh sebab itu evaluasi kinerja unit-unit organisasi dan evaluasi kinerja perorangan perlu dilakukan supaya dapat mengetahui simpul-simpul keterlambatan atau penyimpangan untuk kemudian diatasi dan diperbaiki.

Evaluasi kinerja perusahan dimaksud untuk mengetahui posisi dan tingkat pencapai sasaran perusahaan terutama untuk mengetahui bila terjadi kelambatan atau penyimpangan supaya segera diperbaiki, sehingga sasaran atau tujuan dapat dicapai.

Evaluasi kinerja atau yang dapat pula disebut penilaian prestasi kerja merupakan bagian dari fungsi manajemen yang penting yaitu evaluasi dan pengawasan. Evaluasi kinerja sekarang ini merupakan keharusan dan sudah terus menerus dilakukan terutama dengan melibatkan para pelanggan.

Para pelanggan sering diminta memberikan evaluasi misalnya kualitas pelayaan yang diberikan, sikap karyawan yang melayani. Sebagai bagian dari fungsi manajemen, proses evaluasi kinerja mengikuti tahap perencanan, pembinaan, dan pelaksanan evaluasi.

Evaluasi kinerja merupakan tahap akhir dari siklus manajemen kinerja. Evaluasi kinerja dilakukan untuk mengetahui seberapa jauh rencana kinerja telah telah dilaksanakan dan seberapa jauh tujuan pembinaan kinerja telah dicapai. Evaluasi kinerja tersebut sekaligus harus mampu mengindikasikan masalah yang telah dihadapi semuanya digunakan untuk penyusunan rencana kerja tahap berikutnya.

Menurut Triton.PB (2005:95) tujuan dilakukan penilaian kinerja 
berdasarkan periode waktu adalah sebagai berikut :

1. Untuk memberi dasar bagi rencana dan pelaksanaan pemberian penghargaan bagi karyawan atas kinerja pada periode waktu sebelumnya.

2. Untuk memotivasi.

3. Agar pada periode waktu yang akan datang kinerja seorang karyawan dapat ditingkatkan.

Menurut Triton.PB (2005:95) manfaat penilaian kinerja antara lain adalah :

1. Sebagai dasar informasi dan data untuk pengambilan keputusan menaikan atau menurunkan gaji

2. Sebagai dasar informasi dan data untuk pengambilan keputusan mengenai status karyawan, pemutusan hubungan kerja, demosi dan lain sebagainya.

3. Sebagai dasar informasi dan data untuk kebijakan promosi

4. Sebagai dasar informasi dan data untuk penempatanpenempatan (positioning) karyawan pada tugas-tugas

5. Sebagai dasar informasi dan data untuk menilai efektivitas setiap kegiatan yang ada dalam perusahaan

Agar pelaksanaan penilaian kinerja dapat dilaksanakan dengan baik, perlu dipersiapkan sistem dan cara penilaian kinerja yang sistematik dan konstruktif. Hubangan dengan pekerjaan, sifat kepraktisan, standarstandar, dan ukuran yang dapat diandalkan harus ada dalam sistemsistem penilaian kinerja yang akan diterapkan.

\section{5) Pengertian Efektivitas kerja}

Manajemen yang baik adalah manajemen yang mampu mengorganisasi dan memanfaatkan sumber daya yang tersedia secara efektivitas.

Menurut $\begin{gathered}\text { Sondang } P \text {. Siagian } \\ \text { (2011:3) Efektivitas }\end{gathered}$ adalah
Eeseluruhan proses dalam
keseluruhan proses dalam organisasi dengan memperhatikan pelaksanaan, pembagian kerja, pelimpahan wewenang sehingga tujuan pokok dari organisasi dapat tercapai. Efektivitas juga berkaitan erat bukan hanya dengan pengunaan sumber daya, dana dan prasarana kerja secara tepat, akan tetapi dengan tercapainya tujuan dan sasaran yang telah ditentukan sebelumnya dalam batas waktu yang telah ditetapkan untuk pencapaian.

Menurut Sondang $P$. Siagian (2011 : 30) adalah beberapa faktor yang mempengaruhi efektivitas kerja antara lain :

a) Kepemimpinan yang baik

b) Adanya semangat kerja yang tinggi

c) Adanya usaha untuk meningkatkan produksi

d) Adanya kerja pimpinan dan karyawan

Untuk meningkatkan kemampuan kerja para karyawan. Pimpinan harus menjalankan usahausaha pengembangan karyawan dengan baik dan tujuannya untuk memperbaiki efektivitas kerja karyawan dalam mencapai hasil-hasil kerja yang telah ditetapkan.

Dengan kata lain seorang pimpinan yang baik adalah apabila kebutuhan karyawan dapat dipenuhi, sehingga seorang / karyawan akan berkerja dengan baik dan demikian efektivitas kerja menjadi lebih baik.

Menurut Sondang $P$. Siagian (2011:32-34) adalah hal-hal yang bisa dijadikan pegangan dalam mengukur efektivitas kerja organisasi, kerja organisasi diantaranya adalah : 
a) Kejelasan tujuan yang hendak dicapai

Proses pencapaian tujuan organisasi akan lebih lancar dan efektivitas, apabila para karyawan meyakini dan menyadari kejelasan tentang arti pentingnya pencapaian tujuan pribadi mereka yang dicapai dalam suatu organisasi untuk meningkatkan prestasi kerja .

b) Kejelasan strategi pencapaian tujuan

Strategi bisa dianggap sebagai "pata jalan" dalam usaha mencapai sasaran yang telah ditetapkan karen kejelasan "pata jalan"ini perlu untuk menghindari kemungkinan terjadinya penyimpangan.

c) Proses analisa dan perumusan kebijakan yang mantap

Kegiatan perumusan harus mampu menjembatan tujuan dan usaha-usaha pelaksanaan kegiatan operasional oleh karena itu manajemen harus mampu menterjemakan informasi menjadi data yang dibutukan serta mengolah dan menganalisis sehingga bisa dipakai dasar kebijaksanaan perusahaan.

d) Perencanaan yang matang

Pada hakikatnya merumuskan rencana berarti sekarang apa yang akan dikerjakan organisasi yang akan datang, sampai sejau mana perusahaan dapat memperkirakan keadaan yang dihadapi, mengambil keputusan serta resiko yang akan ditimbulkan dapat dijadikan kriteria efektivitas kerja organisasi. e) Penyusunan program yang tepat

Suatu rencana yang baik masih perlu dijabarkan dalam program pelaksanaan yang tepat pula, jika tidak maka karyawan akan kurang memiliki pedoman dalam bertindak dan berkerja.

f) Tersedianya sarana

Salah satu indikator penting dalam mengukur efektivitas kerja perusahaan adalah kemampuan berkerja secara produktif dengan sarana dan perasarana yang tersedia dalam perusahaan.

g) Pelaksanaan yang efektif dan efisien

Strategi yang tepat proses perumusan yang efektif, rencana yang matang, penjabatan rencana dalam program yang tepat serta kemampuan memfaatkan sarana prasarana yang tersedia harus dicerminkan ke dalam kegiatan operasional yang efektif dan efisien.

Dalam hal demikian efektivitas mencapai tujuan organisasi sangat ditentukan oleh efektivitas pencapaian individu / karyawan dan kelompok. Organisasi yang mampu mencapai efektivitas berarti pula akan memiliki daya saing organisasi dalam jangka panjang. Pengelolaan manajemen sumber daya strategis diperlukan untuk mendorong efektivitas pelaksanaan kerja karyawan sehingga tercapai efektivitas organisasi dalam jangka panjang.

\section{6) Fungsi pengelolaan Sumber Daya Manusia}

Untuk itu setiap organisasi dalam setiap bagian fungsi dan pengelolaan sumber daya manusia, 
memiliki tangung jawab dalam melaksanakan berbagai fungsi dan kebijakan sumber daya manusia. Pencapaian kinerja sumber daya manusia dan organisasi sesungguhnya dapat terwujud melalui suatu proses dalam pelaksanaan strategi objektif perusahaan. Setiap anggota organisasi dituntut juga untuk mempelajari dan mengaplikasi manajemen sumber daya manusia, sehingga dengan langka ini maka setiap individu diharapkan mampu menjalankan tugasnya secara efektif dan efisien. Sasaran dari manajemen sumber daya manusia dalam suatu organisasi adalah bagaimana cara memberikan fasilitas untuk perkembangan pegawai suatu organisasi.

Menurut Sulaiman Sukmalana (2007:106) langkah-langkah kebijakan tersebut mencakup berbagai kebijakan sebagai berikut :

1. Menetapkan suatu tindakan yang efektif untuk meningkatkan kemampuan pada pegawai perusahaan.

2. Merencanakan peningkatan manajemen dan kompensasi para supervisior.

3. Mengevalusi kembali rencana kesejahtraan pegawai.

4. Meningkatkan hubungan para pegawai secara efektif.

Tugas dan pengelolahan fungsifungsi tesebut tidak hanya pada bagian yang khusus saja yang jadi tanggung jawab, melainkan pada pelaksanaan fungsi seluru bagian perusahaan yang berhubungan dengan pengelolaan dan pengendalian potensi serta fungsi sumber daya manusia pada suatu organisasi. Keefektivan seluruh bidang tugas fungsi-fungsi sumber daya manusia dan perannya dalam organisasi akan sangat tergantung pada kemampuan dalam menguasai proses perencanaan kinerja sumber daya manusia dan organisasi.

\section{METODE PENELITIAN}

Metode penelitian yang digunakan dalam penelitian ini adalah metode penelitian Deskriptif Kualitatif. Pengunaan metode dimulai dengan mengumpulkan data, pengelompokan data, menyusun data, menganalisis sehingga memperoleh gambaran baru atau pun menguatkan suatu gambaran yang tidak ada, jadi bentuk analisis ini dilakukan merupakan penjelasan-penjelasan, bukan berupa angka-angka statistik atau bentuk angka lain, dengan tujuan untuk melukiskan sifat dan karakteristik itu sehingga kesimpulan yang diambil mendekati kenyataan yang sebenarnya.

D. POPULASI DAN SAMPEL

1) Populasi

Menurut Sugiono (2015:72)

Populasi adalah subjek yang mempunyai kualitas dan karakteristik tertentu yang ditetapkan oleh peneliti untuk dipelajari dan kemudian ditarik kesimpulan. Populasi adalah seluruh karyawan PT. Bumi Alam Persada Ogan llir yang berjumlah 55 orang.

\section{2) Sampel}

Menurut Sugiono (2015:73) Sampel adalah bagian dari jumlah dan karakteristik yang dimiliki oleh populasi tersebut, dalam penelitian ini penulis menggunakan sampel yang di ambil adalah karyawan PT. Bumi Alam Persada Ogan Ilir berjumlah 35 orang.

Dengan menggunakan pendapat Slovin yang dikutip dari Husein Umar (2010 : 146) $\mathrm{n}=$ $\frac{N}{1+\left(N * e^{2}\right)}$ 
Dimana :

$\mathrm{n}$ : Ukuran Sampel

N : Ukuran Populasi

$\mathrm{e}^{2}$ :Tingkat kesalahan (persentasi kelonggaran tidak kestabilan karena adanya kesalahan pengambilan sampel)

maka jumlah sampel yang diambil jika terjadi tingkat kesalahan sampling sebesar $10 \%$ adalah :

$\mathrm{n}=\frac{55}{1+\left(55^{*} 0,01\right)}$

$n=35$ orang

\section{E. TEKNIK} DATA

PENGUMPULAN

Adapun beberapa teknik yang digunakan dalam pengumpulan data penelitian tersebut menghasilkan dua jenis data diantaranya sebagai berikut :
1) Observasi
Mengumpulkan data atau mengadakan pengamatan langsung tempat dimana penelitian itu dilakukan.
2) Wawancara
Mengumpulkan data dengan tanya jawab kepada pimpinan yang bersangkutan secara terperinci.

\section{F. HASIL DAN PEMBAHASAN}

Sesuai dengan data yang penulis kemukakan dan berdasarkan permasalahan yang dihadapi oleh PT. Bumi Alam Persada Ogan Ilir maka penulis membahas atau menganalisa permasalahan tersebut dengan membandingkan teori-teori yang ada.
1) Peningkatan Kinerja dalam meningkatkan Efektifitas Kerja
Dalam suatu organisasi yang besar sudah tentu akan menghadapi

bermacam-macam masalah, hal ini karena semakin berkembangnya organisasi tersebut dan semakin bertambah kompleksnya kegiatankegiatan yang dilaksanakan. Organisasi sifatnya sudah tentu akan memerlukan orang-orang atau tenaga knerja yang cukup tinggi sehingga mereka bekerja dan berfikir secara kompleks pula.

Pada perusahaan PT. Bumi Alam Persada Ogan Ilir, kinerja mempunyai peranan yang sangat penting dalam aktivitas diperusahaan, dimana setiap bidang bekerja perlu dilakukan dengan perencanaan dan kinerja yang baik. Perencanaan merupakan permulaan dari proses pekerjaan yang mengandung aktivitas-aktivitas yang akan dilaksanakan, yaitu memikirkan sebelumnya apa yang akan dilakukan dan apa tujuan dari yang dilakukan tersebut.

Sedangkan kinerja adalah tingkat pencapaian hasil atas pelaksanaan tugas tertentu. Manajemen kinerja adalah keseluruhan kegiatan yang dilakukan untuk meningkatkan kinerja perusahaan atau organisasi, termasuk kinerja masing-masimg individu dan kelompok kerja di perusahaan tersebut. Tanpa adanya manajemen kinerja yang baik perusahaan tersebut tidak akan tercapai sebagaimana mestinya yang telah ditetapkan.

Berdasarkan pengamatan penulis bahwa pimpinan perusahan PT. Bumi Alam Persada Ogan Ilir, kinerja belum dilaksanakan dengan efektif, karena kurangnya disiplin kerja karyawan antara lain absensi, tugas rangkap. Karena pimpinan dan kepala bagian belum melaksanakan kinerja dengan baik.

Sebagaimana diketahui disiplin adalah salah satu pembinaan semangat atau moril kerja pegawai 
dalam menjalankan tugasnya, supaya tertib, berdaya guna dan berhasil guna untuk meningkatkan efektifitaas kerja karyawan seksi sumber daya manusia PT. Bumi Alam Persada Ogan Ilir perlu meningkatkan kinerja karyawam sebagai berikut :

1. Absensi kehadiran yang dilakukan pada setiap hari kerja pada unit satuan kerja masingmasing.

2. Adanya rekapitulasi absensi karyawan.

3. Daftar hadir dan rekapitulasi dilanjutkan ke kasubag administrasi setelah itu diberikan pada kepala seksi sumber daya manusia PT. Bumi Alam Persada Ogan llir untuk diserahkan kepada kepala cabang.

Kepala seksi Sumber Daya Manusia selalu memberi pengarahan tentang disiplin agar setiap karyawan ditanamkan rasa memiliki terhadap pekerjaanya, kepala seksi sumber daya manusia selalu menegaskan kepada bawahannya mau dibawa kemana PT. Bumi Alam Persada Ogan llir maju atau mundur semuanya tergantung dari sumber daya manusianya.

Bila sumber daya manusia sudah menanamkan rasa disiplin, baik jam kerja maupun dalam menjalankan tugas-tugas yang diberikan oleh pimpinan maka keberhasilan suatu tujuan akan tercapai dengan sebaik mungkin.

4. Pengambilan tabel jam kerja karyawan PT. Bumi Alam Persada Ogan Ilir, jam kerja yang berlaku pada PT. Bumi Alam Persada Ogan llir.

Hari kerja yang berlaku di PT. Bumi Alam Persada Ogan llir yaitu 5 hari kerja sementara hari sabtu libur sesuai dengan ketentuan pemerintah tentang ketenagaan kerjaan.

Sesuai dengan jam kerja masuk karyawan dan pulang bervariasi, hal ini disebabkan adanya alasan seperti jarak dari rumah kekantor jauh. Pelanggaran atas disiplin pegawai seksi sumber daya manusia memberikan tingkat hukuman sebagai berikut :

1. Hukuman Disiplin Ringan
a. Teguran lisan
b. Teguran tertulis
c. Pernyataan tidak puas secara tertulis

2. Hukuman Disiplin Sedang
a. Penundaan kenaikan gaji berkala paling lambat satu tahun
b. Penurunan gaji sebesar satu kali, kenaikan gaji berkala untuk paling lama satu tahun
c. Penundaan kenaikan pangkat untuk paling lama satu tahun

3. Hukuman Disiplin Berat
a. Penurunan pangkat pada npangkat yang setingkat lebih rendah paling lama satu tahun
b. Pembebasan dari jabatan
c. Pemberhentian dengan hormat tidak atas permintaan sendiri
d. Pemberhentian dengan tidak hormat

Namun sejauh ini hukuman yang pernah dilakukan terhadap PT. Bumi Alam Persada Ogan Ilir yaitu teguran secara lisan. Teguran lisan tebagi dalam beberapa tingkat seperti : teguran lisan pertama, bila teguran pertama tidak diindahkan maka diberikan teguran kedua, apabila teguran ini masih oleh pegawai maka tindakan selanjutnya adalah dengan memberikan teguran tertulis. Teguran tertulis ini juga diperingatkan sampai tiga kali.

Berdasarkan teori T. Hani Handoko (2013 : 209) yaitu kegiatan 
yang diambil untuk menangani pelanggaran terhadap aturan-aturan dan mencoba untuk menghindari perlanggaran-pelanggaran lebih lanjut yaitu :

1. Untuk memperbaiki pelanggaran terhadap peraturan yang telah ditetapkan dalam perusahaan.

2. Untuk menghilangi para karyawan yang lain melakukan kesalahan yang serupa.

3. Untuk menjaga berbagai standar kelompok tetap konsisten dan efektif.

Rata-rata manusia tidak menyukai kerja dan akan menghindarnya jika mungkin karena sifat manusia tidak menyukai kerja, tapi ingin mendapatkan hasil yang besar sebagai orang harus dipaksa dikendalikan, diarahkan dan diancam dengan hukuman untuk membuat mereka supaya berusaha, menghadapi manusia seperti ini memang sulit karena pimpinan harus banyak berperan aktif untuk melihat bawahannya. Orang yang memiliki sifat seperti ini cocok diberikan motivasi atau dorongaan yang bersifat ancaman atau hukuman, dengan demikian mereka akan merasa takut untuk tidak mengerjakan tugas yang dibebankan kepadanya dan merasa diawasai terus-menerus.

Untuk itu pimpinan perlu mengadakan usaha untuk meningkatkan efektifitas kerja dan menerapkannya dengan baik. Namun untuk mendapatkan efektifitas kerja yang baik unsur pimpinan PT. Bumi Alam Persada Ogan llir menciptakan suasana kerja yang dapat meningkatkan kerja sama dalam menjalankan tugas kantor sehingga beban tugas tidak dirasakan sebagai suatu beban yang berat. Akan tetapi merupakan kewajiban yang harus dilaksanankan dengan penuh rasa tanggung jawab. Yang perlu diperhatikan oleh pimpinan dalam melaksanakan disiplin kerja adalah masuk atau pulang kerja tepat pada waktunya, kepada bawahan bersifat membimbing serta mengarahkan. Dengan pemberian hukuman karyawan merasa takut apabila tidak mentaati disiplin jam kerja. Diharapkan karyawan tidak melakukan kebiasaan datang terlambat kekantor.

\section{2) Upaya untuk meningkatkan Efektifitas kerja}

Untuk mengatasi hambatanhambatan tersebut maka diadakan upaya-upaya untuk mengatasinya yaitu :

1. Menetapkan standar pelaksanaan / perencanaan Perencanaan harus ditetapkan terlebih dahulu agar tidak terjadi penyimpangan-penyimpangan sehingga tujuan dari pada organisasi dapat dilaksanakan sesuai rencana sebelumnya

2. Penentuan pengukuran pelaksanaan kegiatan

3. Pengukuran pelaksanaan kegiatan nyata

4. Perbandingan pelaksanaan kegiatan dengan standar dan penganalisaan penyimpanganpenyimpangan

Dengan demikian hasil kerja dapat sesuai dengan rencana, jika dihubungkan dengan perusahaan PT. Bumi Alam Persada Ogan Ilir tampak bahwa pelaksanaan kinerja belum dilaksanakan dengan begitu baik.

Setelah itu jika terdapat kesalahan dengan kata lain hasil yang dicapai lebih kecil dari yang ditargetkan maka perlu diambil 
tindakan perbaikan agar setiap rencana untuk masa yang akan datang dapat dilaksanakan lebih efektif.

Dengan adanya kinerja yang efektif, maka kesalahan yang tidak sesuai dengan tugas dan wewenang yang telah ditentukan dapat dicegah atau diperbaiki, sehingga kemungkinan timbulnya kerugian yang besar dapat dihindari atau setidaknya dapat diperkecil dan akhirnya dapat menimbulkan keuntungan bagi perusahaan. Penempatan orang-orang yang sesuai dengan bidangnya dan kemampuannya adalah sangat perlu sekali karena dengan menempatkan orang-orang yang tepat pada bidang yang sesuai dengan kemampuan akan sangat berperan bagi kelanjutan usaha dalam suatu perusahaan.

Dengan adanya pembagian kerja bagi setiap orang tersebut maka akan timbul pula tanggung jawab yang harus dipikul sesuai dengan beban dan tugas masing-masing kelancaran kerja dan semangat kerja yang tinggi akan timbul sehingga pencapaian tujuan dan sasaransasaran perusahaan diharapkan akan dapat dicapai sesuai dengan rencana.

\section{3) Pendelegasian Wewenang Masalah pendelegasian} wewenang didalam perusahaan ini, mencakup pendelegasian wewenang dari pimpinan, baik kepada kepala cabang maupun kepala bagian lain. Pendelegasian wewenang adalah merupakan tindakan pemberian wewenang yang dilakukan oleh pimpinan yang satu kepada pimpinan yang lainnya dan juga merupakan suatu proses kegiatan dari seorang pimpinan untuk menugaskan bawahannya untuk melaksanakan bagian dari tugas pimpinan yang bersangkutan dan pada waktu yang bersamaan memberikan kekuasaan pada bawahannya tersebut, sehingga bawahannya itu dapat mempertanggung jawabkan hal-hal yang didelegasikan kepadanya.

Adanya

pendelegasian wewenang berarti pimpinan tersebut akan mengkonsentrasikan diri pada tugas-tugas dengan lebih baik, yang menyangkut masa depan perusahaan dengan demikian perusahaan yang pimpinan harapkan dapat mencapai tujuan sesuai dengan harapan yang di inginkan.

Dalam pendelegasian sebagian wewenang kepada bawahan, maka bawahan yang menerima haruslah bertanggung jawab sepenuhnya akan apa yang telah dibebankan kepadanya yaitu berupa tugas-tugas yang harus dikerjakan sehingga pimpinan akan dapat menilai hasil kerja bawahan tersebut.

Kalau diperhatikan pada kantor cabang PT. Bumi Alam Persada Ogan llir, yang dalam kegiatan operasionalnya bergerak dalam bidang jasa terhadap kesejahteraan pegawai negeri / peserta dan keluarganya maka pendelegasian wewenang sering terjadi didalam kantor.

Jadi setiap kepala bagian bertanggung jawab atas segala bentuk kesalahan pada bagian mereka masing-masing, serta segera melaporkan kesalahan itu kepada pimpinan untuk menetapkan tindakan apa yang akan dilakukan untuk mengantisipasinya.

Dengan begitu kinerja yang ada diperusahaan ini akan lebih efektif dan efisien, karena dari laporan itu pimpinan akan lebih mudah memonitor dan mengarahkan bila mana ada kegiatan yang ada diluar rencana yang telah ditetapkan perusahaan. Bila kinerja seperti ini dapat dilaksanakan dengan baik 
maka perusahaan akan dapat mengantisipasi segala bentuk kesalahan yang mungkin akan terjadi dimasa yang akan datang.

\section{F. KESIMPULAN DAN SARAN}

Berdasarkan data yang telah diuraikan terdahulu, maka penulis akan memberikan beberapa kesimpulan dan saran-saran sebagai alternatif untuk pengembangan sistem kinerja dalam perusahaan PT. Bumi Alam Persada Ogan Ilir.

\section{1) Kesimpulan}

Berdasarkan uraian-uraian di atas, maka dapat ditarik suatu kesimpulan sebagai berikut :

a. Untuk dapat terwujudnya pelaksanaan kerja dengan baik dalam usaha meningkatkan efektivitas kerja, maka faktor manusia perlu diperhatikan karena manusia merupakan faktor yang paling penting dalam menentukan berhasil atau tidaknya melaksanakan tugas dan tanggung jawab yang dibebankan kepada mereka dengan sebaik-baiknya.

b. Pada PT. Bumi Alam Persada Ogan Ilir Kegiatan efektivitas kerja belum dilaksanakan sepenuhnya dimana masih adanya tugas rangkap yang dilaksanakan di dalam PT. Bumi Alam Persada Ogan llir. Seorang pemimpin harus bisa menempatkan orang-orang yang sesuai dengan bidang dan kemampuan masing-masing agar tujuan dan sasaran dapat tercapai sesuai dengan rencana

\section{2) Saran-saran}

Berdasarkan kesimpulankesimpulan di atas, maka dapatlah ditarik suatu saran yang mungkin berguna bagi PT. Bumi Alam Persada Ogan Ilir antara lain : a. Untuk lebih meningkatkan efektivitas kerja sehingga dapat melaksanakan pekerjaan secara efektif dan efisien sebaiknya jabatan rangkap harus dihindari.

b. Untuk lebih meningkatkan efektivitas kerja, hendaknya seorang pimpinan harus lebih memperhatikan pengetahuan, keterampilan dan pengembangan kemampuan bagi karyawan, caranya dengan mengadakan pendidikan dan pembinaan sehingga karyawan tersebut akan lebih menyadari terhadaptugas dan tanggung jawab yang dibebankan kepadanya.

c. Pimpinan sebaiknya dapat mendelegasikan wewenang kepada bawahannya sesuai dengan keahlian yang dimiliki agar efektivitas kerja dapat tercapai dan sesuai dengan tujuan yang diharapkan.

\section{DAFTAR PUSTAKA}

Handoko, T. Hani. 2013. Manajemen Personalia dan SDM. (ed.2). Yogyakarta, Indonesia: BPFE

PB. Triton. 2005. Pradigma Baru Manajemen Sumber Daya Manusia. Cetakan ke. 1. Yogyakarta : Tugu Publisher.

Siagian, Sondang. P. 2011. Teori Motivasi dan Aplikasinya. Cetakan Pertama. Jakarta. Bina aksara.

Stoner. A. F. James. 1997. Manajemen. Edisi 2 Jakarta : Erlangga.

Sugiyono. 2015. Metode Penelitian Bisnis. Bandung : Alfabet. 
$\begin{array}{cc}\text { Sukamala Suelaiman. } & 2007 . \\ \text { Manajemen Kinerja } & \text { Pusat } \\ \text { Pengembangan } & \text { Bisnis } \\ \text { Manajemen. Jakarta } & \text { PT. } \\ \text { Intermedia Personalia } & \end{array}$
Umar, Husein. 2007. Evaluasi Kinerja Perusahaan. Jakarta Gramedia Pustaka Utama.

Umar, Husein. 2010. Riset Pemasaran dan Bisnis. Jakarta : Gramedia Pustaka Utama. 